Guzman, V.L., C.A. Sanchez, and R.E. Lucas. 1987. Banding fertilizers for improved fertilizer use efficiency for lettuce on Everglades histosols. Proc. Fla. State Hort. Soc. 100:200-203.

Jones, L.G. and G.F. Warren. 1954. The efficiency of various methods of application of phosphorus for tomatoes. Proc. Amer. Soc. Hort. Sci. 63:309-319.

Kemble, J.M. and E.A. Guertal. 1996. Comparison of band and broadcast applications of phosphorus on sweet corn yield. HortScience 31:757-758.

Locascio, S.J. 1987. Progress in nutrition of Florida vegetables during the past 100 years. Proc. Fla. State Hort. Soc. 100:398-405.

Locascio, S.J. and J.G.A. Fiskell. 1976. Pepper production as influenced by mulch, fertilizer placement, and nitrogen rate. Proc. Soil Crop Sci. Soc. Fla. 36:113-117.

Locascio, S.J., J.G.A. Fiskell, and F.G. Martin. 1972. Influence of fertilizer placement and micronutrient rate on watermelon composition and yield. J. Amer. Soc. Hort. Sci. 97:119-123.

Locascio, S.J., G.F. Warren, and G.E. Wilcox. 1960. The effect of phosphorus placement on uptake of phosphorus and growth of direct-seeded tomatoes. Proc. Amer. Soc. Hort. Sci. 76:503-514.

Mortley, D.G., C.B. Smith, and K.T. Demchak. 1991. Fertilizer placement affects growth, fruit yield, and elemental concentrations and contents of tomato plants. J. Amer. Soc. Hort. Sci. 116:659662.

Nettles, V.F. 1938. Results from three methods of applying fertilizer to certain vegetables. Proc. Amer. Soc. Hort. Sci. 36:505-508.

Nettles, V.F. and W.C. Hulburt. 1966. Effect of placements and levels of fertilizer on the yield of vegetables. Proc. Fla. State Hort. Soc. 79:185-191.

Parish, R.L., R.P. Bracy, and P.E. Bergeron. 1992. Precision cultural practices for commercial vegetable production. La. Agr. Expt. Sta. Bul. 836. La. State Univ, Agr. Ctr., Baton Rouge.

Sanchez, C.A., P.S. Porter, and M.F. Ulloa. 1991. Relative efficiency of broadcast and banded phosphorus for sweet corn produced on histosols. Soil Sci. Soc. Amer. J 55:871-875

Sanchez, C.A., S. Swanson, and P.S. Porter. 1990. Banding $P$ to improve fertilizer use efficiency of lettuce. J. Amer. Soc. Hort. Sci. 115:581-584.

Sogaard, H.T. and P. Kierkegaard. 1994 Yield reduction resulting from uneven fertilizer distribution. Trans. ASAE $37(6): 1749-1752$.

Hort technology • October-December $1997 \quad 7(4)$

\section{Applications of Endothalic Acid, Pelargonic Acid, and Hydrogen Cyanamide for Blossom Thinning in Apple and Peach}

\section{Esmaeil Fallahi ${ }^{1}$}

\section{Adoitional index words. Dormex, 1 - naphthyl- $N$-methylcarbamate, carbaryl, Sevin, NAA, Thinex, Endothal, NAA, Malus domestica, Prunus persica}

Summary. Blossom thinning of 'Early Spur Rome' apple (Malus domestica Borkh.) and 'Redhaven' peach (Prunus persica L.) with hydrogen cyanamide (Dormex, 50\% a.i.), endothalic acid [(Endothal, 0.4 lb a.i./gal (47.93 $\mathrm{g}$ a.i./L)], and pelargonic acid (Thinex, $60 \%$ a.i.) was studied in 1995 and 1996. Fullbloom applications of hydrogen cyanamide at 2 pt formulation $/ 100$ gal (1288 $\mathrm{mg}$ a.i. $/ \mathrm{L})$ and $2.5 \mathrm{pt}$ formulation /100 gal (1610 mg a.i./ L) or endothalic acid at $1 \mathrm{pt}$ formulation/100 gal (59.9 $\mathrm{mg}$ a.i./L), once at $70 \%$ bloom and again at full bloom, reduced apple fruit set. Pelargonic acid was only effective in thinning apple blossoms when applied twiceat $40 \%$ bloom and again at full bloom-at $1.5 \mathrm{pt}$ formulation $/ 100$ gal $(1.12 \mathrm{~mL}$ a.i. $/ \mathrm{L})$ per application. Pelargonic acid marked apples in 1995 but not 1996. Neither hydrogen cyanamide nor endothalic acid marked

${ }^{1}$ Associate professor, Tree Fruit Physiologist University of Idaho, Department of Plant, Soil and Entomological Scicnces, Parma Research and Extension Center, 29603 U of I Lane, Parma Idaho 83660.

I wish to express my appreciation to the Idaho Apple Commission, Elf Atochem, N.A., D.K. International, Inc, and Mycogen Corp for their financial support of this project. I am also thankful to Tom Lyon (Wilbur Ellis, Inc.), Bahar Fallahi, and David Rudell, Jr., for their technical assistance, and to Williamson Fruit Ranch, J.C. Watson, Inc., and Ray Obendorf and Bruce Ponder of Parma Orchards for contributing apples and peaches to this project. The cost of publishing this paper was defrayed in part by the payment of page charges. Under postal regulations, this paper therefore must be hereby marked advertisement solely to indicate this fact. apples. A single full-bloom application of hydrogen cyanamide, endothalic acid, or pelargonic acid effectively thinned peach blossoms in 1995; however, in 1996, only hydrogen cyanamide at $2.5 \mathrm{pt}$ formulation $/ 100$ gal effectively thinned peach blossoms. Peaches did not show fruit marks with any of the peach blossom thinners.

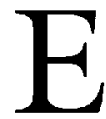
arly thinning of apples is important because of its impact on fruit size and the next season's flower bud initiation. In the past, apple cultivars were often sprayed with the blossom thinner sodium dinitro-ortho-cresol (Elgetol, $19 \%$ a.i.) during full bloom, followed by a postbloom application of a fruit thinner such as I-naphthyl-Nmethylcarbamate (carbaryl) with or without naphthalene acetic acid (NAA) (Williams and Edgerton, 1981). Carbaryl and NAA are effective postbloom fruit thinners for 4 to 5 weeks after full bloom (Byers et al., 1990; Byers and Carbaugh, 1991; Williams and Edgerton, 1981). Gibberellin $\mathrm{A}_{4+7}$ and 6-benzylamino purine are also effective postbloom fruit thinners for ' $\mathrm{De}$ licious' apples (Byers and Carbaugh, 1991; Ferree, 1996; Greene, 1984; Greene and Lord, 1985). Elgetol was removed from the market in 1989 because of the high cost of reregistration. Full-bloom sprays of sulfcarbamide (Wilthin, $79 \%$ a.i.), pelargonic acid (Thinex), and endothalic acid (Endothal) or petal fall applications of carbaryl (Sevin XLR Plus) were developed as replacements for Elgetol and were reported to result in a satisfactory thinning and fruit set in 'Delicious' apple (Williams, 1993, 1994).

Hydrogen cyanamide and other chemicals have been used to eliminate or to reduce chilling requirements of peaches grown under the warm desert conditions of southwestern Arizona (Fallahi et al., 1990). Hydrogen cyanamide applied at "pink bloom" stage reduced the number of open blooms. Based on this observation, hydrogen cyanamide at different concentrations was sprayed at prebloom and full bloom on 'Florda Prince' peach in southwestern Arizona (Fallahi et al., 1990). Under the climatic conditions of that experiment, applying hydrogen cyanamide at $8 \mathrm{pt}$ formulation $/ 100 \mathrm{gal}$ (5152 $\mathrm{mg}$ a.i./L) at full bloom signifi- 
cantly reduced fruit set. Hydrogen cyanamide also was found to be an effective blossom thinner for plums in Idaho (Fallahi et al., 1992). Effectiveness of hydrogen cyanamide and sulfcarbamide in blossom thinning of 'Law Rome Beauty' apple was recently reported by Fallahi et al. (1997).

The objective of this experiment was to study effects of hydrogen cyanamide, endothalic acid, and pelargonic acid as blossom thinners on 'Early Spur Rome' apple and 'Redhaven' peach.

\section{Materials and methods}

Hydrogen cyanamide (Dormex, $50 \%$ a.i., D.K. International, Inc., Marietta, Ga.), endothalic acid [Endothal, $0.4 \mathrm{lb}$ a.i./gal (47.93 g a.i./L), Elf Atochem, N.A., Philadelphia], and pelargonic acid [Thinex, $57 \%$ pelargonic acid $(4.2 \mathrm{lb}$ pelargonic acid/gal; $0.5 \mathrm{~kg}$ pelargonic acid/L) and $3 \%$ related fatty acids as active ingredients (total a.i. $=60 \%$ ), Mycogen Corp, San Diego, Calif.] were used as blossom thinners for 'Early Spur Rome' apple and 'Redhaven peach. Polyoxye thylenepolypropoxypropanol (Regulaid, 90.6\% a.i.) was used with all pelargonic acid treatments, and modified phthalic glycerol alkyd resin (Latron B-1956, a.i. 77\%) was used with all hydrogen cyanamide treatments as surfactants in apple and peach experiments in 1995 and 1996.
Endothalic acid sprays were not mixed with any surfactant.

Apple thinning trials. The study was conducted during the 1995 and 1996 growing seasons. Six- and sevenyear-old 'Early Spur Rome' apple trees on M.26 EMLA rootstock with 'Delicious' interstems at a $12 \times 18-\mathrm{ft}(3.65$ $\times 5.5-\mathrm{m}$ ) spacing in a commercial orchard near Parma, Idaho, were used. In 1996, a different set of trees in the same orchard as 1995 was used. Trees in 1995 and 1996 were in full production without any freeze injury. Except for blossom and fruit thinning, cultural practices in this orchard were similar to those of commercial orchards. The experimental design in each year was a completely randomized design with six one-tree replications per treatment. On different sides of each tree, four $5.9-\mathrm{ft}(1.8-\mathrm{m})$ limbs were arbitrarily selected and tagged and all flower buds (mixed buds) were counted $\approx 2$ weeks before bloom (before any treatment application). All fruit on the tagged limbs were counted after June drop on 1 June 1995 and 12 June 1996 , and the number of fruit per 100 flower clusters was calculated.

Apple trees were in full bloom ( $\approx 85 \%$ to $90 \%$ of all blooms open) on 3 May 1995 and 30 Apr. 1996. Trees were at $\approx 70 \%$ bloom on $30 \mathrm{Apr} .1995$ and at $\approx 40 \%$ bloom on 26 Apr. 1996 . Apple trees were sprayed to runoff with a hand-gun sprayer at 100 psi. The volume of liquid sprayed was $\approx 1.3$ gal $(4.9 \mathrm{~L})$ per tree at each application. This volume was equivalent to $\approx 262$ $\mathrm{gal} /$ acre $\left(\approx 2451 \mathrm{~L} \cdot \mathrm{ha}^{-1}\right)$.

Treatments for the apple experiment in 1995 and 1996 are listed in Tables 1 and 2 . Control trees received no chemical or hand thinning. In the hand-thinning treatment (only in 1996), fruit were hand thinned (no chemical thinning) to one fruit per cluster when the fruit diameter was $\approx 0.70$ inches $(18 \mathrm{~mm}$ ) on 12 June 1996. Fruit set in this treatment was determined after hand thinning. In the postbloom and hand-thinning treatment, fruit were thinned with a postbloom application of carbaryl [Sevin XLR Plus, 4 lb a.i./gal $(0.48 \mathrm{~kg}$ a.i. L)] mixed with Regulaid in 1995 and with carbaryl mixed with NAA [NAA-200, $0.44 \mathrm{lb} / \mathrm{gal}$ (52.7 g a.i.) L)] and Regulaid in 1996 at the rates described in Tables 1 and 2 . In this treatment, fruit on the tagged limbs were counted before hand thinning to determine the effect of postbloom fruit thinners alone on fruit set. Fruit on the whole tree were then hand thinned to one fruit per cluster on 9 June 1995 and on 12 June 1996. This treatment is similar to the current commercial thinning practice. In 1995, postbloom thinner was not applied to trees that had received a blossom-thinning treatment. In 1996, however, trees in certain blossom thinning treatments received a mixture of postbloom chemical thinner at the rates described in Table 2 .

Table 1. Effects of blossom thinners on fruit set, fruit weight, and yield of 'Early Spur Rome' apple in $1995 .^{\mathrm{z}}$

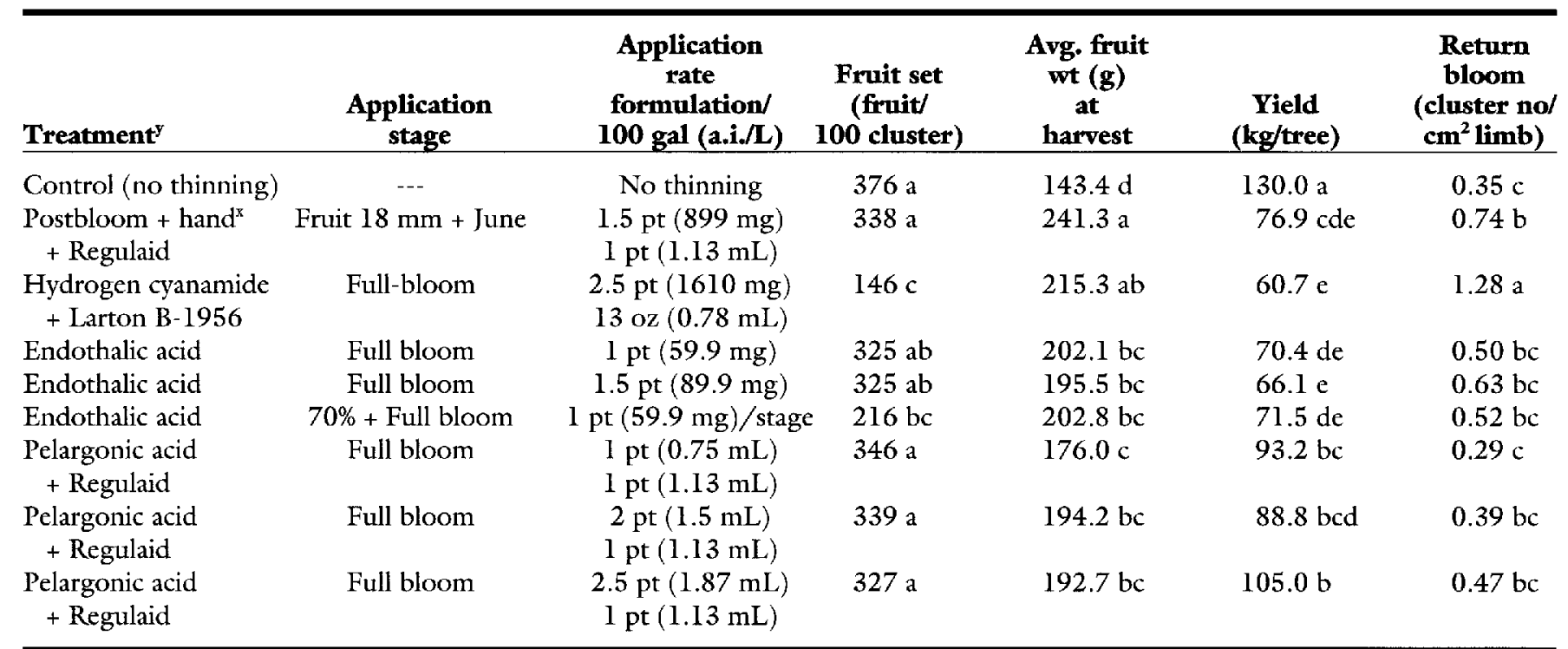

${ }^{7}$ Mean separation within columns with Tukey's studentized test at $P=0.05$.

yo follow-up postbloom thinner was applied after any of the blossom thinners in 1995.

xostbloom + hand = Carbaryl (Sevin XLR Plus) at the $1.5 \mathrm{pt}$ formulation $/ 100 \mathrm{gal}$ ( $899 \mathrm{mg}$ a.i. $/ \mathrm{L}$ or $0.187 \% \mathrm{v} / \mathrm{v}$ ) mixed with Regulaid at the $1 \mathrm{pt}$ formulation $/ 100 \mathrm{gal}$ ( 1.13 $\mathrm{mL}$ a.i./L) was applied for postbloom fruit thinning when fruit were $=18 \mathrm{~mm}$ in diameter. Fruit were then hand thinned to one fruit per cluster in June. 
Peach thinning trials. Twelveyear-old 'Redhaven' peach trees on peach seedling rootstock at a $18 \times 18$ $\mathrm{ft}(5.5 \times 5.5-\mathrm{m})$ spacing in a commercial orchard in the Sunny Slope area, near Caldwell, Idaho, were used. In 1996, a different set of trees than that in 1995 was used. Trees in 1995 suffered a minor freeze damage before blossom thinning, but they still had moderately heavy bloom. Trees in 1996 had heavy bloom without any freeze injury. Except for blossom and hand thinning, other cultural practices in this experiment were similar to those of commercial orchards. The experimental design in each year was a completely randomized design with six one-tree replications per treatment. On different sides of each tree, four $4.9-\mathrm{ft}(1.5-\mathrm{m})$ limbs were tagged and all flower buds were counted $\approx 12$ days before bloom (before any treatment application). All fruit on the tagged limbs were counted after June drop on 2 June 1995 and 7 June 1996, and the number of fruit per 100 flowers was calculated.

Peach trees were in full bloom $(\approx$ $85 \%$ to $100 \%$ of all blooms open) on 10 Apr. 1995 and on 9 Apr. 1996. Trees were at $\approx 75 \%$ bloom on 7 Apr. 1996 (application time for treatment 6, Table $3)$. Peach trees were sprayed to runoff with a motorized hand-gun sprayer.
The volume of liquid sprayed per tree at each application was $\approx 2$ gal $(7.6 \mathrm{~L})$. This volume was equivalent to $\approx 269$ $\mathrm{gal} /$ acre $\left(\approx 2514 \mathrm{~L} \cdot \mathrm{ha}^{-1}\right)$.

Treatments of the peach experiment in 1995 and 1996 are listed in Table 3 . In the hand-thinning treatment (only in 1996), fruit were hand thinned to maintain a 6 to 7 -inch (15.2 to $17.8-\mathrm{cm}$ ) space between fruit before pit hardening stage on 7 June 1996. The fruit set in this treatment was determined based on the number of fruit after hand thinning per 100 flowers. This treatment did not receive any blossom thinner and is similar to the current commercial practice.

Fruit yielo and quality evaluaTION. Each year, yield per tree for apple and peach was recorded, and 30 fruit per tree were taken for weight and color measurements. Fruit color was measured with similar procedures as those described by Fallahi and Simons (1993). Since larger fruit were always heavier, fruit weight is used throughout the manuscript to also indicate fruit size. About 50 fruit per tree (if that many are available) were sampled and polished, and the percentage of fruit with severe marks was calculated for each year.

\section{Results and discussion}

Apple experiment. Fruit set re- duction with applications of postbloom fruit thinners alone (without any blossom thinner) before hand thinning was not significant in 1995 (Table 1 ) or 1996 (Table 2), perhaps because the rates of postbloom thinners was not high enough to thin effectively. In the postbloom + hand-thinning treatment, average fruit weight at the time of thinning (June) was slightly greater than that of nonsprayed control (data not shown). At harvest, fruit size in this treatment tended to be larger (and often significantly) than all treatments except those with hydrogen cyanamide spray at $2.5 \mathrm{pt}$ formulation $/ 100$ gal in 1995 and 1996. Fruit set in this treatment was measured just before hand thinning, but harvest fruit weight was measured several weeks after hand thinning. Therefore, a combination of the slight initial fruit weight increase due to postbloom fruit thinners and subsequent hand thinning resulted in larger fruit at harvest.

Compared to control trees, applying hydrogen cyanamide at the $2 \mathrm{pt}$ formulation $/ 100 \mathrm{gal}$ in 1996 and the $2.5 \mathrm{pt}$ formulation/100 gal in 1995 and 1996 significantly reduced fruit set and increased fruit size (Table 1 and 2). In these trees, a significant reduction in the number of fruit led to a higher leaf-to-fruit ratio, resulting in larger fruit. Trees sprayed with hydro-

Table 2. Effects of blossom thinners on fruit set, fruit weight, and yield of 'Early Spur Rome' in $1996 .^{\mathrm{z}}$

\begin{tabular}{|c|c|c|c|c|c|c|}
\hline Treatment & $\begin{array}{c}\text { Application } \\
\text { stage }\end{array}$ & $\begin{array}{c}\text { Application } \\
\text { rate } \\
\text { formulation/ } \\
100 \text { gal (a.i./L) }\end{array}$ & $\begin{array}{c}\begin{array}{c}\text { Postbloom } \\
\text { thinner }\end{array} \\
\end{array}$ & $\begin{array}{c}\text { Fruit set } \\
\text { (fruit/ } \\
100 \text { clusters) }\end{array}$ & $\begin{array}{c}\text { Avg. } \\
\text { fruit (g) } \\
\text { at } \\
\text { harvest }\end{array}$ & $\begin{array}{c}\text { Yield } \\
\text { (kg/tree) }\end{array}$ \\
\hline $\begin{array}{l}\text { Control } \\
\text { (No thinning) }\end{array}$ & -- & None & None & $156 \mathrm{a}$ & $113.0 \mathrm{~d}$ & $101.4 \mathrm{a}$ \\
\hline $\begin{array}{l}\text { Postbloom + hand. }{ }^{x y} \\
+ \text { Regulaid }\end{array}$ & Fruit $18 \mathrm{~mm}+$ June & $\begin{array}{l}\text { See footnote }{ }^{x y} \\
1 \mathrm{pt}(1.13 \mathrm{~mL})\end{array}$ & Sevin + NAA & $151 \mathrm{ab}$ & $202.4 \mathrm{a}$ & $49.0 \mathrm{~b}$ \\
\hline Hand thin only & June & None & None & $84 \mathrm{~d}$ & $173.1 \mathrm{abc}$ & $64.0 \mathrm{~b}$ \\
\hline $\begin{array}{l}\text { Hydrogen cyanamide } \\
\text { + Larton B-1956 }\end{array}$ & Full bloom & $\begin{array}{c}2 \mathrm{pt}(1288 \mathrm{mg}) \\
13 \mathrm{oz}(0.78 \mathrm{~mL})\end{array}$ & Sevin + NAA & $87 \mathrm{~cd}$ & $175.8 \mathrm{abc}$ & $74.0 \mathrm{ab}$ \\
\hline $\begin{array}{l}\text { Hydrogen cyanamide } \\
\text { + Larton B-1956 }\end{array}$ & Full bloom & $\begin{array}{l}2.5 \mathrm{pt}(1610 \mathrm{mg}) \\
13 \mathrm{oz}(0.78 \mathrm{~mL})\end{array}$ & Sevin + NAA & $95 \mathrm{~cd}$ & $179.9 \mathrm{ab}$ & $58.6 \mathrm{~b}$ \\
\hline Endothalic acid & Full bloom & $\mathrm{l} \mathrm{pt}(59.9 \mathrm{mg})$ & None & $121 \mathrm{abcd}$ & $115.6 \mathrm{~d}$ & $83.5 \mathrm{ab}$ \\
\hline Endothalic acid & Full bloom & $1 \mathrm{pt}(59.9 \mathrm{mg})$ & Sevin + NAA & $83 \mathrm{~d}$ & $168.0 \mathrm{abc}$ & $58.0 \mathrm{~b}$ \\
\hline $\begin{array}{c}\text { Pelargonic acid } \\
\text { + Regulaid }\end{array}$ & Full bloom & $\begin{array}{c}1.5 \mathrm{pt}(1.12 \mathrm{~mL}) \\
1 \mathrm{pt}(1.13 \mathrm{~mL})\end{array}$ & Sevin + NAA & $137 a b c$ & $128.9 \mathrm{~cd}$ & $59.6 \mathrm{~b}$ \\
\hline $\begin{array}{l}\text { Pelargonic acid } \\
\text { + Regulaid }\end{array}$ & $40 \%+$ Full bloom & $\begin{array}{c}1.5 \mathrm{pt}(1.12 \mathrm{~mL}) \\
1 \mathrm{pt}(1.13 \mathrm{~mL})\end{array}$ & Sevin + NAA & $99 \mathrm{bcd}$ & $167.9 \mathrm{abc}$ & $57.8 \mathrm{~b}$ \\
\hline $\begin{array}{l}\text { Pelargonic acid } \\
\text { + Regulaid }\end{array}$ & Full bloom & $\begin{array}{c}2.5 \mathrm{pt}(1.87 \mathrm{~mL}) \\
1 \mathrm{pt}(1.13 \mathrm{~mL})\end{array}$ & Sevin + NAA & $124 \mathrm{abcd}$ & $145.4 \mathrm{bcd}$ & $63.9 \mathrm{~b}$ \\
\hline
\end{tabular}

${ }^{z}$ Mean separation within columns with Tukey's studentized test at $P=0.05$.

${ }^{x y}$ Postbloom thinner (when applied) consisted of carbaryl (Sevin XLR Plus) at 1 pt formulation $/ 100$ gal (588 mg a.i. $/ \mathrm{L}$ or $0.125 \% \mathrm{v} / \mathrm{v}$ ) mixed with NAA (NAA-200) at 1 o7 formulation $/ 100 \mathrm{gal}\left(4.1 \mathrm{mg}\right.$ a.i. $/ \mathrm{L}$ or 78.1 ( $\left.\mu \mathrm{L} \cdot \mathrm{L}^{-1}\right)$ plus Regulaid at $1 \mathrm{pt}$ formulation $/ 100 \mathrm{gal}(1.13 \mathrm{~mL}$ a.i. $/ \mathrm{L})$, applied when fruit diameter was $\approx 18 \mathrm{~mm}$. In postbloom + hand treatment, in addition to the postbloom thinner, fruit were hand-thinned to one fruit/cluster in June. 
gen cyanamide showed symptoms of leaf burning and chlorosis on spur leaves a few days after application. Most of the phytotoxicity symptoms dissipated as the foliage grew, and only minor symptoms were visible on spur leaves at the time of harvest. These symptoms did not have an adverse effect on yield or fruit size. Hydrogen cyanamide did not cause any fruit marks throughout this experiment.

Applications of endothalic acid at the $1 \mathrm{pt}$ formulation/100 gal at $70 \%$ bloom and again at full bloom significantly reduced fruit set and increased fruit size in 1995 (Table 1). A single full-bloom application of endothalic acid at either a 1 or $1.5 \mathrm{pt}$ formulation $/ 100 \mathrm{gal}$ in 1995 , or at a $1 \mathrm{pt}$ formulation/l00gal in 1996 without any postbloom thinner, did not reduce fruit set (Tables 1 and 2). However, when a full-bloom application of endothalic acid at the $1 \mathrm{pt}$ formulation $/ 100$ gal was followed by a postbloom application of carbaryl and NAA in 1996, fruit set and yield were significantly reduced and fruit size increased (Table 2). Applying endothalic acid, particularly at high concentrations, induced leaf burning, but the damage was dissipated by the end of growing season. Endothalic acid did not cause fruit marks in this experiment.

Applications of pelargonic acid at the $1.5 \mathrm{pt}$ formulation/ 100 gal, once when $40 \%$ of blossoms were open and again at full bloom, followed by a postbloom application of carbaryl and NAA significantly reduced fruit set and yicld and an increased fruit size in 1996 (Table 2). Reduced fruit set in the trees that received a single application of pelargonic acid at full bloom at rates of 1 to $2.5 \mathrm{pt}$ formulation/ 100 gal was not significant in 1995 or 1996 (Tables 1 and 2). However, reduced fruit set in the trees sprayed with pelargonic acid at the $2.5 \mathrm{pt}$ formulation $/ 100 \mathrm{gal}$ was drastic enough to reduce yield in 1995 and 1996 significantly and to increase fruit size in 1995. Fruit from trees treated with pelargonic acid, particularly from those with the $2.5 \mathrm{pt}$ formulation $/ 100 \mathrm{gal}$, had significantly higher fruit marks in 1995 but had no marks in 1996 (data not shown). Temperatures during fullbloom applications were 48 to $53{ }^{\circ} \mathrm{F}$ (8.9 to $11.7^{\circ} \mathrm{C}$ ) in 1995 and 60 to 65 ${ }^{\circ} \mathrm{F}\left(15.6\right.$ to $18.3{ }^{\circ} \mathrm{C}$ ) in 1996. Maximum temperatures on the days of applications at full bloom were $65^{\circ} \mathrm{F}$ $\left(18.3^{\circ} \mathrm{C}\right)$ in 1995 and $72^{\circ} \mathrm{F}\left(22.2^{\circ} \mathrm{C}\right)$ in 1996. The weather was calm and sunny during application days in both years. Thus, the presence of fruit marks in the trees sprayed with pelargonic acid in 1995 could be due to a slower drying condition in 1995 than in 1996.

In an one-season experiment with two rates of endothalic acid and pelargonic acid, Williams (1994) observed that full-bloom applications of endothalic acid at the 1 or $2 \mathrm{pt}$ formulation/ $100 \mathrm{gal}(119.8 \mathrm{mg}$ a.i./L) or pelargonic acid at the 1 or $2 \mathrm{pt}$ formulation/100 gal significantly reduced fruit set in 'Delicious' and 'Granny Smith'. In 'Fuji' apple, however, only endothalic acid at $2 \mathrm{pt}$ formulation/ $100 \mathrm{gal}$ or pelargonic acid at the $2 \mathrm{pt}$ formulation $/ 100 \mathrm{gal}$ effectively thinned. Similar to 'Fuji', 'Early Spur Rome' is considered a hard-to-thin cultivar. Lack of effective thinning in the trees treated with a single spray of endothalic acid at the $1 \mathrm{pt}$ formulation $/ 100 \mathrm{gal}$ or with pelargonic acid at the $1 \mathrm{pt}$ formulation/ $100 \mathrm{gal}$ at full bloom in this experiment agrees with the results in 'Fuji' (Williams, 1994).

Compared to all treatments, trees sprayed with hydrogen cyanamide at the $2.5 \mathrm{pt}$ formulation $/ 100$ gal at full bloom in 1995 had significantly higher return bloom in 1996 because this treatment effectively reduced fruit set and yield in 1995 (Table 1). Nontreated control trees and those sprayed with pelargonic acid at the $\mathrm{l} \mathrm{pt}$ formulation/100 gal in 1995 had the lowest return bloom in 1996. The heavy fruit set in 1995 resulted in biennial bearing in these trees.

Peach experiment. Full-bloom applications of hydrogen cyanamide, endothalic acid, or pelargonic acid at all rates significantly reduced fruit set in 'Redhaven' peach in 1995 (Table $3)$. Reduced fruit set in these treatments resulted in significantly reduced yields in 1995. Trees sprayed with hydrogen cyanamide at the $2.5 \mathrm{pt}$ formulation/100 gal or with endothalic acid at the $1.5 \mathrm{pt}$ formulation/ $100 \mathrm{gal}$ had significantly lower fruit set than those treated with pelargonic acid and had significantly larger fruit than those of nonsprayed control trees in 1995.

Table 3. Effects of blossom thinners on fruit set, fruit weight, and yield of 'Redhaven' Peach in 1995 and $1996 .{ }^{\mathrm{z}}$

\begin{tabular}{|c|c|c|c|c|c|c|c|c|}
\hline Control (no thinning) & --- & --- & $6.04 \mathrm{a}$ & $5.21 \mathrm{a}$ & $177.4 \mathrm{c}$ & $107.3 \mathrm{~b}$ & $189.0 \mathrm{a}$ & $97.0 \mathrm{a}$ \\
\hline $\begin{array}{l}\text { Hand thinning } \\
\text { (No chemical thinning) }\end{array}$ & Before pit hard & --- & $\cdots$ & $2.37 \mathrm{c}$ & --- & $145.5 \mathrm{a}$ & --- & $60.3 \mathrm{~b}$ \\
\hline $\begin{array}{l}\text { Hydrogen cyanamide } \\
\text { + Larton B-1956 }\end{array}$ & Full bloom & $\begin{array}{l}2.5 \mathrm{pt}(1610 \mathrm{mg}) \\
13 \mathrm{oz}(0.78 \mathrm{~mL})\end{array}$ & $1.10 \mathrm{~d}$ & $2.61 \mathrm{bc}$ & $265.2 \mathrm{a}$ & $138.4 \mathrm{ab}$ & $24.8 \mathrm{c}$ & 82.1 ab \\
\hline Endothalic acid & Full bloom & $1 \mathrm{pt}(59.9 \mathrm{mg})$ & $1.64 \mathrm{~cd}$ & $4.19 \mathrm{abc}$ & $200.9 \mathrm{bc}$ & $111.8 \mathrm{~b}$ & $56.3 \mathrm{c}$ & $81.1 \mathrm{ab}$ \\
\hline Endothalic acid & $75 \%+$ Full bloom & $1 \mathrm{pt}(59.9 \mathrm{mg}) / \mathrm{stage}$ & $-\cdots$ & $4.57 \mathrm{ab}$ & $\cdots$ & $112.5 \mathrm{~b}$ & -- & $84.3 \mathrm{ab}$ \\
\hline Endothalic acid & Full bloom & $1.5 \mathrm{pt}(89.9 \mathrm{mg})$ & $1.20 \mathrm{~d}$ & $--\cdot$ & $205.3 \mathrm{~b}$ & -- & $42.0 \mathrm{c}$ & --- \\
\hline
\end{tabular}

${ }^{2}$ Mean separation within columns by Tukey's studentized test at $P=0.05$. 
Blossom thinners were less effective in 1996 than 1995 (Table 3), perhaps because of different pollination and fertilization conditions that existed during these 2 years. Temperatures during treatment applications were $\approx 48$ to $51{ }^{\circ} \mathrm{F}\left(8.9\right.$ to $\left.10.6^{\circ} \mathrm{C}\right)$, with a daily maximum of $53^{\circ} \mathrm{F}$ (11.7 ${ }^{\circ} \mathrm{C}$ ), in 1995 and 65 to $70^{\circ} \mathrm{F}$ ( 18.3 to $21.1^{\circ} \mathrm{C}$ ), with daily maximum of 80 ${ }^{\circ} \mathrm{F}\left(26.7^{\circ} \mathrm{C}\right)$, in 1996. Excellent weather conditions, such as several calm and sunny days with maximum temperatures of 64 to $80^{\circ} \mathrm{F}$ ( 17.8 to $26.7^{\circ} \mathrm{C}$ ), and good bee activity contributed to better pollination and fertilization in 1996 and, thus, lower response of blossom thinners. Applying hydrogen cyanamide at the 2.5 pt formulation/100 gal, even under these ideal pollination and fertilization conditions, significantly reduced fruit set compared to the control. Hydrogen cyanamide at this rate reduced fruit set to a level similar to the hand-thinned tree. Fruit weight from trees sprayed with hydrogen cyanamide at the $2.5 \mathrm{pt}$ formulation/ $100 \mathrm{gal}$ were only $7.1 \mathrm{~g}$ lower than those from hand-thinned trees in 1996 (Table 3). However, fruit from hand-thinned trees had more uniform color than those from chemically thinned trees due to a better fruit spacing and less fruit-to-fruit shading effects.

Similar to the situation in the apple experiment, applying endothalic acid, particularly at high concentrations, induced minor leaf burning in peach, but the damage was dissipated by the end of growing season. None of the blossom thinners at any concentration caused fruit marks (data not shown).

\section{Conclusions}

Time and temperature are very important factors influencing the effectiveness of blossom thinning in apple and peach. It is essential that blossom thinners be applied when some, but not all, fertilization has taken place. Also, the severity of frost damage must be considered before determining rates of any blossom thinner. Temperature affects bee activity and, subsequently, the number of fertilized flowers. Temperature also affects the chemical characteristics and the effectiveness of blossom thinners such as hydrogen cyanamide. Therefore, the effect of these blossom thinners should be tested for each geographical region and for each cultivar. Also, effectiveness of these blossom thinners, when sprayed with an air-blast sprayer, should be tested before applying the rates discussed in this paper at a commercial scale.

Under conditions of this study, hydrogen cyanamide was an effective blossom thinner for 'Early Spur Rome' apple and 'Redhaven' peach when applied at full bloom. Endothalic acid at the $1 \mathrm{pt}$ formulation/100 gal was an effective blossom thinner for 'Early Spur Rome' apple if application was followed by a mixture of postbloom fruit thinner or when applied twice, once at $=70 \%$ bloom and again at full bloom. Pelargonic acid at the $1.5 \mathrm{pt}$ formulation $/ 100 \mathrm{gal}$ was also an effective blossom thinner in 'Early Spur Rome' apple if applied once at $\approx 40 \%$ bloom and again at full bloom. Pelargonic acid at other concentrations did not effectively thin apple blossoms. In I year out this 2-year study, pelargonic acid caused fruit marks in apple. Endothalic acid at the 1 or $1.5 \mathrm{pt}$ formulation $/ 100 \mathrm{gal}$ or pelargonic acid at the 2 or 3 pt formulation $/ 100 \mathrm{gal}$ effectively thinned peach blossoms in 1 year of this experiment.

\section{Literature cited}

Byers, R.E. and D.H. Carbaugh. 1991. Effects of chemical thinning sprays on apple fruit set. HortTechnology $1:$ 41-48.

Byers, R.E., J.A. Barden, and D.H. Carbaugh. 1990. Thinning spur 'Delicious' apple by shade terbacil, carbaryl, and ethephon. J. Amer. Soc. Hort. Sci. 115:9-13.

Fallahi, E., M. Kilby, and J.W. Moon. 1990. Effects of various chemicals on dormancy, maturity and thinning of peaches. Deciduous Fruit and Nut, Univ, of Arizona Series P-83. p. 121-128.

Fallahi, E., B.R. Simons, J.K. Fellman, and W.M. Colt. 1992. Use of hydrogen cyanamide for apple and plum thinning. Plant Growth Regulat. 11: 435-439.

Fallahi, E. and B.R. Simons. 1993. Influence of fruit spacing on fruit quality and mineral partitioning of 'Redchief Delicious' apple under full crop conditions. Fruit Var. J. 47:172-178.

Fallahi, E., M.W.Williams, and W.M. Colt. 1997. Blossom thinning of 'Law Rome Beauty' apple with hydrogen cyanamide and monocarbamide dihydrogensulfate. J. Tree Fruit Prod. (In press.)

Ferrec, D.C. 1996. Performance of benzyladenine as a chemical thinner on eight apple cultivars. J. Fruit Prod. 1:33-50.

Greene, D.W. 1984. Microdroplet application of $\mathrm{GA}_{4+7}+\mathrm{BA}$ : Sites of absorption and effects on fruit set, size, and shape of 'Delicious' apples. J. Amer. Soc. Hort. Sci. 109:28-30.

Greene, D.W. and W.J. Lord. 1985. Effects of chemical thinners on 'Delicious' apple trees previously sprayed with $\mathrm{GA}_{4+7}$ +BA. HortScience 20:84-86.

Williams, M.W. 1993. Comparison of NAA and carbaryl petal-fall sprays of apples. HortTechnology 3:428-429.

Williams, M.W. 1994. Factors influencing chemical thinning and update on new chemical thinning agents. Compact Fruit Tree 27:115-122.

Williams, M.W. and Edgerton. 1981. Fruit thinning of apples and pears with chemicals. USDA Agr. Bul. 289. 